\title{
Cutaneous malignant melanoma incidences analyzed worldwide by skin type over advancing age of males and females: Evidence estrogen and androgenic hair are risk factors
}

\author{
Dianne E Godar*1, Madhan Subramanian², Stephen J Merrill ${ }^{3}$ \\ ${ }^{1}$ Division of Human Disease Research Worldwide, Body of Knowledge, Inc., USA \\ ${ }^{2}$ Department of Biomedical Engineering, George Washington University, Washington DC, USA \\ ${ }^{3}$ Department of Mathematics, Statistics and Computer Science, Marquette University, Milwaukee, USA
}

Received: August 25, 2016

DOI: $10.5430 /$ jer.v3n1p42

\author{
Accepted: December 7, 2016 Online Published: December 21, 2016 \\ URL: http://dx.doi.org/10.5430/jer.v3n1p42
}

\begin{abstract}
We previously analyzed cutaneous malignant melanoma (CMM) incidences worldwide by sex, age, and Fitzpatrick skin type over time (1955-2007) and found only European-ancestry populations have exponential increasing incidences and about a 2-log increase in the risk between the youngest age groups (0-14 and 15-29 yr). We proposed the increasing incidence over time may be from the spread of Human Papilloma Virus (HPV) found in CMM biopsies, and that the 2-log incidence increase between the youngest age groups might be from developing androgenic hair. The increasing incidence with age may be from white hairs transmitting UV radiation to follicular melanocytes. Here we analyzed CMM incidences over the advancing age of males and females of every skin type (I-VI) worldwide. We found only European-ancestry females have a linear increase in their CMM risk while males of all races have a power function increase in their risk with advancing age. We propose the gradual loss of HPV-infected androgenic follicles with advancing age of only European-ancestry females during and after menopause significantly reduces their CMM risk compared to all males who do not have significant estrogen loss and consequent loss of androgenic hair with advancing age. All other races have females with significantly lower amounts of androgenic body hair so that its loss with advancing age is not significant. These results combined with those in the literature and our previous findings showing CMM has been increasing over time, suggests estrogen synergizes HPV infection of androgenic follicular melanocytes significantly increasing the risk for getting CMM.
\end{abstract}

Key Words: Aging, Hair follicle, Hormones, HPV, Menopause, Ultraviolet radiation

\section{INTRODUCTION}

Many risk factors have been associated with the initiation and propagation of cutaneous malignant melanoma (CMM) including sunlight exposure, DNA damage (both direct and indirect), ozone depletion, sunburn and sunscreens, photosensitive drugs, cosmetic ingredients, indoor environment, artificial UV lamps and ionizing radiation, endogenous and exogenous sex hormones, especially estrogen, pregnancy,

\footnotetext{
*Correspondence: Dianne E Godar; Email: diannegodar@yahoo.com; Address: Body of Knowledge, Inc., 326 Main Street, Division of Human Disease Research Worldwide, Racine, WI 53403, USA.
} 
skin type and melanocytic hyperpigmentation, family history (germline mutations), and DNA polymorphisms. We previously found the incidence of CMM has been increasing exponentially exclusively in European-ancestry populations by analyzing the worldwide temporal (1955-2007) incidences of males and females in five age groups (0-14, 15-29, 30-49, 50-69, 70-85+) with Fitzpatrick skin types I-VI ${ }^{[1,2]}$ in 57 countries on six continents using data from the International Agency for Research on Cancer (IARC) ${ }^{[3]}$ To explain this temporal exponential increase in CMM, we suggested the observed increasing Human Papilloma Virus (HPV) infection of nevi and immune-privileged hair follicles ${ }^{[4]}$ along with decreasing vitamin $\mathrm{D}_{3}$ levels over the past few decades, as reflected by the inversely related parathyroid hormone, ${ }^{[5]}$ are responsible.

HPV infection is increasing at an exponential rate in both Europe $^{[6]}$ and the United States (U.S. $)^{[7]}$ and support for a role of vitamin $\mathrm{D}_{3}$ came from our analysis of European CMM incidences which showed a significant increase occurs with decreasing UVB dose after $1960 .{ }^{[8]}$ HPV is found in CMM biopsies, nevi, ${ }^{[9]}$ and hair follicles that contain stem cells. ${ }^{[10]}$ HPV expedients transformation by inactivating p53, $\mathrm{pRB}$, and vitamin $\mathrm{D}_{3}$ receptor initiated apoptotic pathways so that the cell survives even with DNA damage. ${ }^{[1-13]}$ The importance of vitamin $\mathrm{D}$ is reflected by the fact that CMM patients had deficient and insufficient prediagnostic vitamin $\mathrm{D}_{3}$ levels $^{[14]}$ and survived longer if they got regular sun exposures. ${ }^{[15]}$ Furthermore, outdoor workers have twice the vitamin $\mathrm{D}_{3}$ levels as indoor workers ${ }^{[16]}$ and they have about half the risk for getting CMM. ${ }^{[17]}$ And along with providing another apoptotic pathway for melanoma cells through the vitamin $\mathrm{D}_{3}$ receptor, ${ }^{[13]}$ vitamin $\mathrm{D}_{3}$ boosts the immune system by enabling $\mathrm{T}$ cells to become activated so they can kill virally infected and malignant cells. ${ }^{[18]}$ Paradoxically, in Europe, we found significantly higher CMM incidences occur with lower UVB doses ${ }^{[8]}$ and besides suggesting lower levels of vitamin D may be involved, the findings could also implicate higher levels of UVA exposure in the etiology, as we and others have previously hypothesized. ${ }^{[19,20]}$

Besides the temporal increase in the incidence of CMM, we also observed a dramatic 2-log increase in the CMM incidence between age groups 0-14 and 15-29. ${ }^{[1]}$ Curiously, only the European-ancestry Spanish, Italian, and Israeli skin type III-VI populations had similar CMM profiles as the European-ancestry skin type I-III populations, while the non-European skin type III-IV populations like the Chinese, Japanese, or South Americans (including Koreans and Thai's, results not shown) had lower CMM incidences that decreased or remained stable over time and did not display the dramatic 2-log increase in incidence between the youngest age groups.

Published by Sciedu Press
We proposed the dramatic increase in the incidence of CMM between the youngest age groups is from developing androgenic body hair because European descendants have the most. One can obtain some support for this idea by comparing the distribution of CMM with the distribution of androgenic body hair over male and female body sites. Males have more hair that is androgenic on their face, neck, and torso while females have more hair that is androgenic on their lower limbs ${ }^{[21]}$ coincident with the body sites CMM is found most frequently. ${ }^{[22]}$

Because outdoor workers have a lower CMM incidence than indoor workers, ${ }^{[17]}$ yet they get three to ten times the annual UV radiation (UVR; $290 \mathrm{~nm}-400 \mathrm{~nm}$ ) dose that indoor workers get, ${ }^{[23]}$ we know the cumulative dose of UVR is not involved in CMM. So why does the incidence of CMM increase with increasing age if it is not from cumulative UVR doses? We proposed the increasing CMM incidence with increasing age may be from increasing reactive oxygen species (ROS) creating white hair that can transmit UVA radiation $(316 \mathrm{~nm}-400 \mathrm{~nm})$ along with visible light and possibly some UVB radiation ( $290 \mathrm{~nm}-315 \mathrm{~nm}$ ) to follicular melanocytes and stem cells in the bulge and root areas of the hair follicle. ${ }^{[24]}$ We can obtain some supporting evidence for this idea from the gray horse model that has protective black skin and does not get melanoma until its hair turns white. ${ }^{[25]}$

Here we investigated the role of age and skin type in the etiology of CMM, in order to address the question raised by a previous investigation as to why fair-skinned women have a linear increase in the incidence of CMM with advancing age while fair-skinned men have a power function. ${ }^{[26]}$ The investigators proposed a role for estrogen. To help answer this question, we analyzed the CMM incidences over the advancing age of males and females with Fitzpatrick skin types I-VI in 57 countries on six continents using data from IARC. ${ }^{[3]}$ In agreement with previous analysis using U.S. data for $2005,{ }^{[26]}$ we also found the incidence of CMM increases with advancing age as a non-linear, usually power function increase for all skin type I-III males, while it increases linearly for skin type I-III females. However, our analysis of the world's different populations revealed that not only do fair-skinned people have this phenomena but that all European-ancestry females have a linear increase in the incidence of CMM regardless of skin type (I-III or III-IV) while all males of European or any other-ancestry have a non-linear, power function increase in the incidence of CMM with advancing age. Here we propose an answer to the intriguing question, "Why does CMM increase linearly over age exclusively in European females regardless of skin type?" 


\section{MethodS}

2.1 Analysis of CMM incidence by sex and skin type over the age of the individual

We analyzed the CMM incidences over the advancing age of males and females with Fitzpatrick skin types I-III, III-IV, IV$\mathrm{V}$, and $\mathrm{V}-\mathrm{VI}^{[2]}$ around the world using IARC's age-adjusted, world population normalized data for the 5-year midpoint of 2005 (2003-2007). ${ }^{[3]}$ We plotted average ages for the different age groups, i.e., 0-14 (7 yr), 15-29 (22 yr), 30-49 (40 yr), 50-69 (60 yr) and 70-85+ (80 yr) and aggregated the regional registries for some countries to estimate national CMM incidence trends. In order to show that the method of analysis did not yield misleading results, i.e., using an average age for each age group range, we also analyzed skin type I-III New Zealand males and females every 5 years of age from ages $0-5$ to $80-85+$ in the year 2005 .

To possibly obtain more hints into the etiology of CMM beyond sex, age, and personal UVR dose, we normalized the incidence data for all ages 0-85+ of males and females (averaged) by personal UVR dose and looked at skin types around the world in the year 2005 .

We analyzed 57 countries in total; the data shown here is for Australia, the U.S. (white, other white, or non-Hispanic
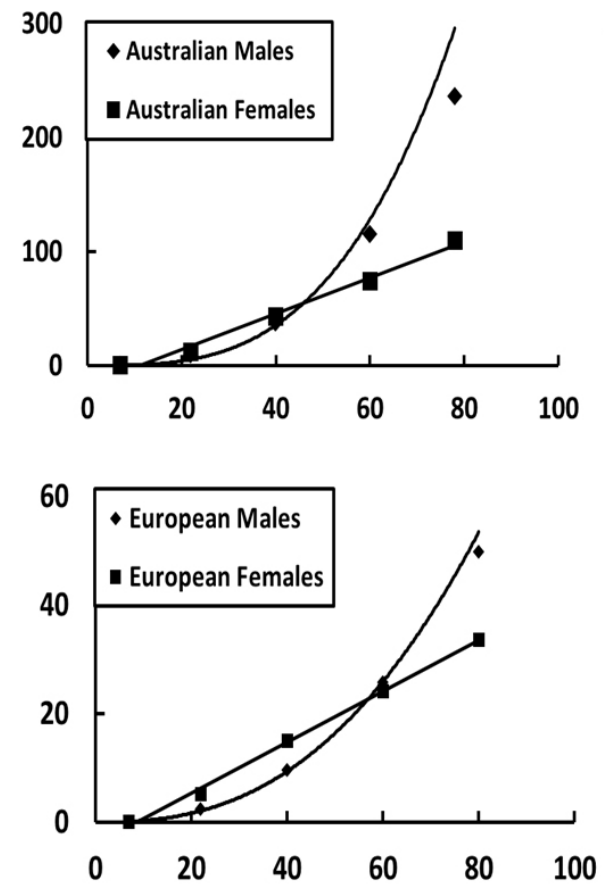

white), Europe (24 countries average shown), China, South America (6 countries average shown), Spain, Italy, Israel, New Zealand (Maoris), India, Africa (8 countries average shown), and the U.S. African-American blacks. The data for the countries analyzed but not shown here are New Zealand (non-Maori whites), Canada, Japan, Cuba, Cyprus, Korea, Kuwait, Malta, Philippines, Portugal, and Thailand.

The specific inclusion criterion was compilation in the last volume of the CI5 series (volume X). The quality control involved a detailed assessment of the validity, completeness, and comparability of the incidence data; these details are provided online (http://ci5.iarc.fr/CI5I-X/old/vol10/I_08.pdf). IARC's CMM data includes all tumor stages, histological subtypes, thicknesses, and body site locations.

Other details of this analysis, including the skin types and countries used are given in reference 1 .

\section{RESULTS}

We began by analyzing the CMM incidence of primarily skin type I-III populations in Australia, U.S., Europe, and Canada, and curiously found that females display a linear trend over advancing age, whereas, males have an increasing non-linear power function over advancing age (see Figure 1).
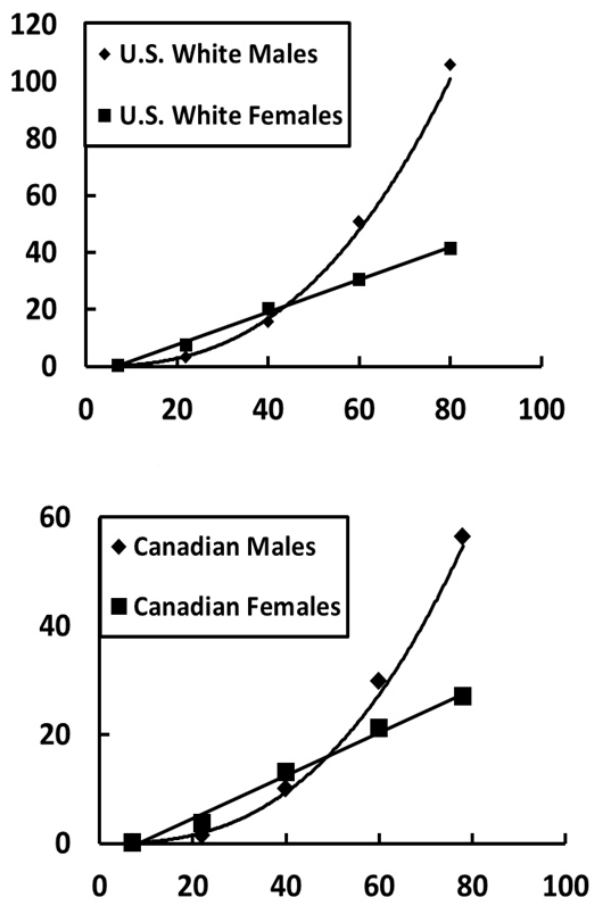

Figure 1. Age-standardized CMM cases per 100,000 people by age of Australian, U.S., European, and Canadian males and females with pale skin tone and Fitzpatrick skin type I-III 
In contrast to the skin type I-III populations around the world, tions over advancing age of both females and males, except the skin type III-IV populations with yellow skin tone have for the Spanish population residing in Spain (see Figure 2). lower incidences and only display non-linear power func-
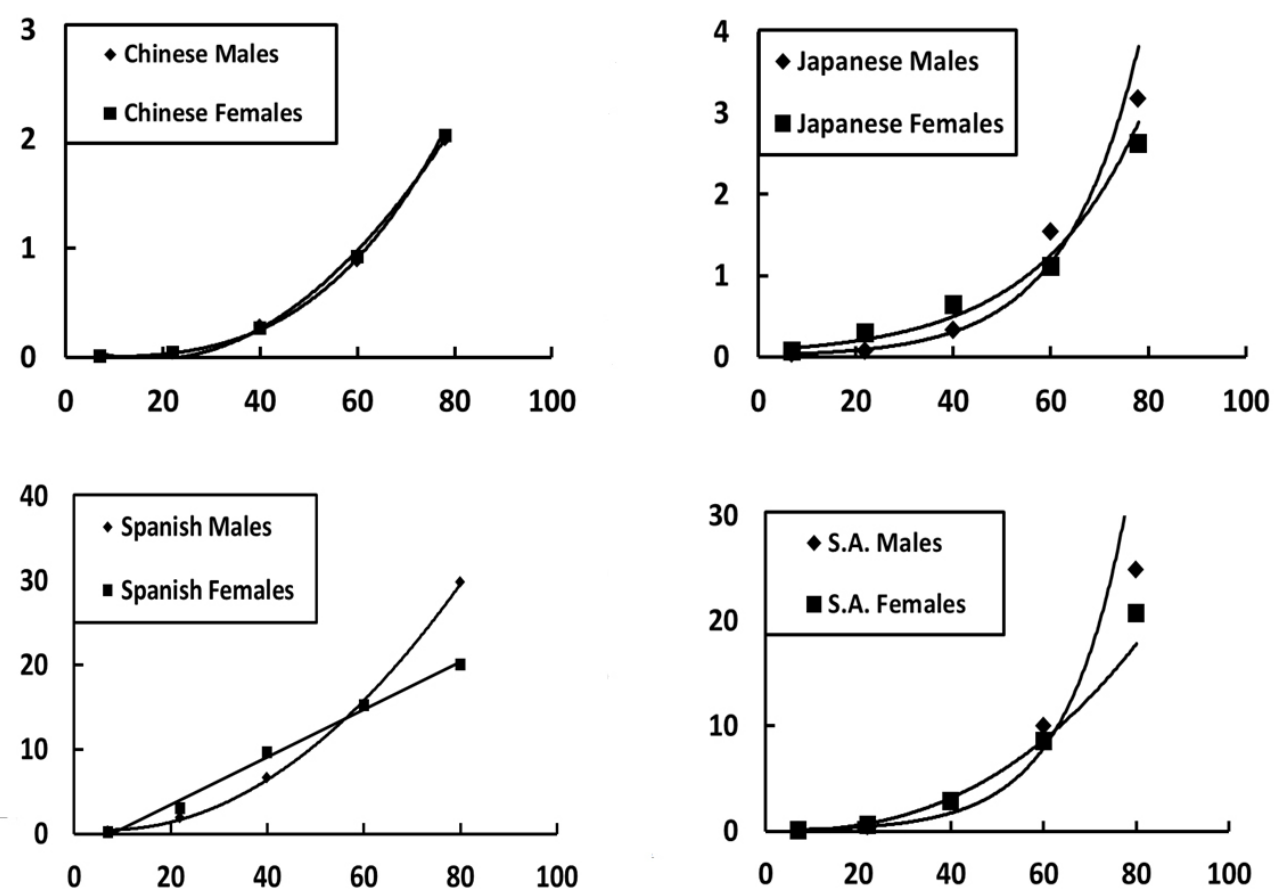

Figure 2. Age-standardized CMM cases per 100,000 people by age of Chinese, Japanese, Spanish, and South American (S.A in Figure) males and females with yellow skin tone and Fitzpatrick skin type III-IV
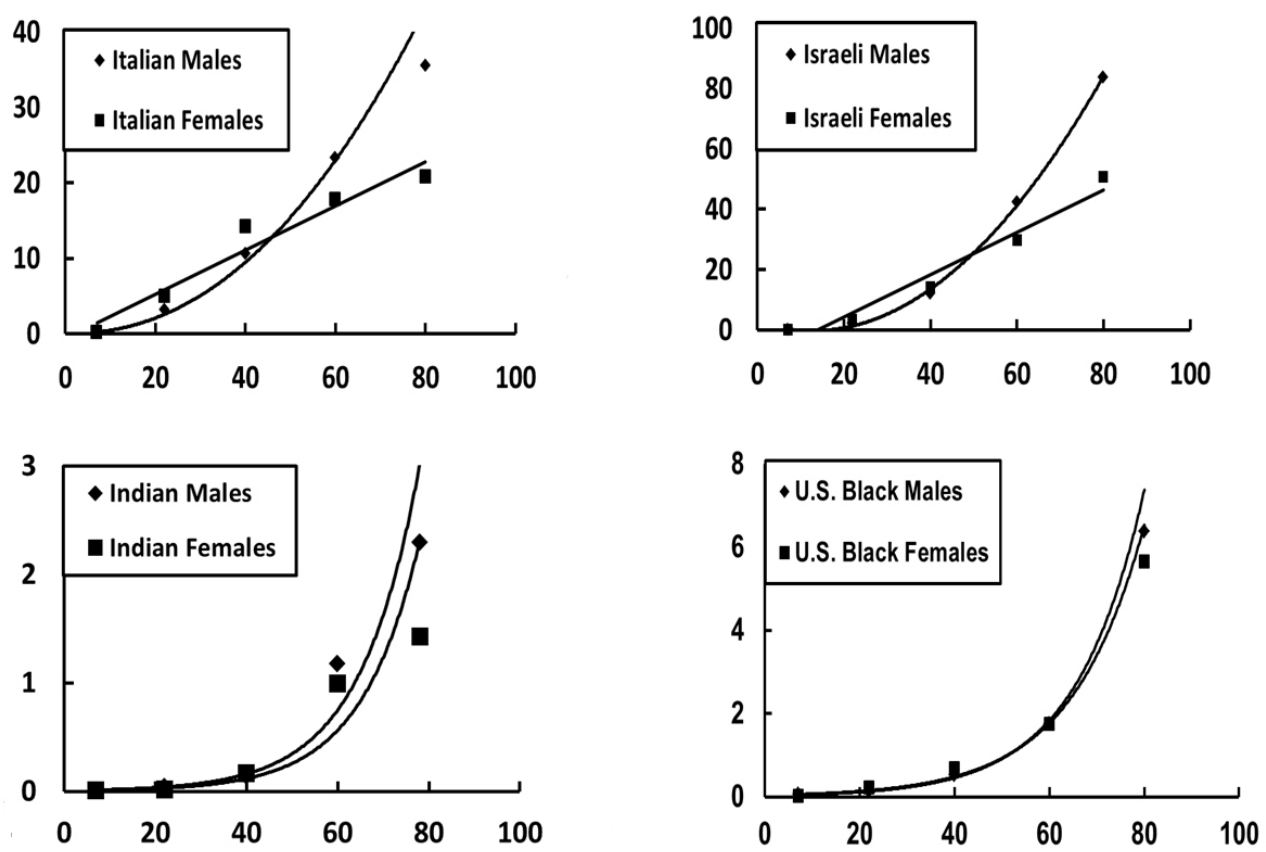

Figure 3. Age-standardized CMM cases per 100,000 people by age of Italian and Israeli males and females with olive skin tone and Fitzpatrick skin type III-IV; eastern Indian males and females with brown skin tone and Fitzpatrick skin type IV-V; U.S. African American males and females with brown to black skin tone and Fitzpatrick skin type IV-VI 
The skin type III-IV Europeans with olive skin tone of Italians and Israelis only had females displaying a linear function over advancing age (see Figure 3 top panels) similar to skin type I-III and skin type III-IV Europeans with yellow skin tone (Spanish females), whereas the males all displayed nonlinear power functions over advancing age. However, the skin type IV-V populations in India (see Figure 3, bottom left panel) or the native Polynesian Maori population residing in New Zealand or the native Polynesian Hawaiian population in Hawaii (results not shown) with skin type III-IV along with the African skin types III-VI (results not shown) and U.S. African-American black skin tone populations with skin types IV-VI (see Figure 3 bottom right panel) all have non-linear power functions for both males and females.

Because the method of analysis involved an average age for the different age group ranges, the data plots might be deceivingly linear or another mathematical function. To know how the incidence of CMM really increases with advancing age and what mathematical function really applies to European descendants, we analyzed males and females in New Zealand every 5 years of age (see Figure 4). The linear increase for females and power function for males persisted.

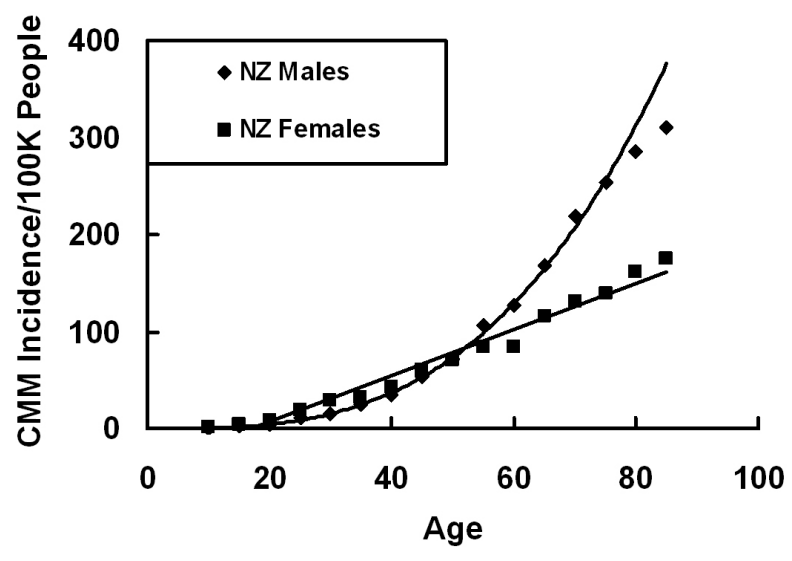

Figure 4. Age-standardized CMM cases per 100,000 people by every five years of age of New Zealand (NZ in Figure) males and females with pale skin tone and Fitzpatrick skin type I-III

To obtain more information on the etiology of CMM beyond sex, age, and UVB dose, we averaged the CMM incidences of males and females of all ages 0-85+ and normalized by personal, residential UVB dose ${ }^{[8]}$ to compare the different skin types in countries around the world. Figure 5A shows the European-ancestry populations with skin type I-III in Australia ([CMM incidence 21.12/100K people $\left./ \mathrm{J} / \mathrm{m}^{2}\right]$ $\left.\times 10^{-3}\right)$ and New Zealand ([33.47/100K people $\left./ \mathrm{J} / \mathrm{m}^{2}\right] \times$ $10^{-3}$ ) have about two and three times the CMM incidences, respectively, as the skin type I-III population in the U.S. $\left(\left[12.34 / 100 \mathrm{~K}\right.\right.$ people $\left.\left./ \mathrm{J} / \mathrm{m}^{2}\right] \times 10^{-3}\right)$, Europe $([11.47 / 100 \mathrm{~K}$ people $\left.\left./ \mathrm{J} / \mathrm{m}^{2}\right] \times 10^{-3}\right)$, or Canada $\left(\left[15.51 / 100 \mathrm{~K}\right.\right.$ people $\left./ \mathrm{J} / \mathrm{m}^{2}\right]$ $\times 10^{-3}$ ), which have similar CMM incidences. Figure 5B shows the Asian populations with skin type III-IV and yellow skin tone in China $\left(\left[0.25 / 100 \mathrm{~K}\right.\right.$ people $\left./ \mathrm{J} / \mathrm{m}^{2}\right] \times$ $\left.10^{-3}\right)$, Japan $\left(\left[0.41 / 100 \mathrm{~K}\right.\right.$ people $\left.\left./ \mathrm{J} / \mathrm{m}^{2}\right] \times 10^{-3}\right)$, and Korea $\left(\left[0.58 / 100 \mathrm{~K}\right.\right.$ people $\left.\left./ \mathrm{J} / \mathrm{m}^{2}\right] \times 10^{-3}\right)$ have much lower CMM incidences compared with the skin type I-III populations and have about five to 20 times lower incidences as the same skin type and yellow skin tone Spanish populations in South America $\left(\left[2.60 / 100 \mathrm{~K}\right.\right.$ people $\left.\left./ \mathrm{J} / \mathrm{m}^{2}\right] \times 10^{-3}\right)$ and Spain $\left(\left[4.70 / 100 \mathrm{~K}\right.\right.$ people $\left.\left./ \mathrm{J} / \mathrm{m}^{2}\right] \times 10^{-3}\right)$. Figure $5 \mathrm{C}$ shows skin type III-IV with olive skin tone Italians ([6.51/100K people $\left./ \mathrm{J} / \mathrm{m}^{2}\right] \times 10^{-3}$ ) and tan skin tone Polynesian Maori's in New Zealand $\left(\left[5.82 / 100 \mathrm{~K}\right.\right.$ people $\left.\left./ \mathrm{J} / \mathrm{m}^{2}\right] \times 10^{-3}\right)$ have about half the CMM incidence as skin type I-III populations in the U.S., Europe, and Canada, while skin type IV-V eastern Indians $\left(\left[0.20 / 100 \mathrm{~K}\right.\right.$ people $\left.\left./ \mathrm{J} / \mathrm{m}^{2}\right] \times 10^{-3}\right)$ and skin type III-VI in Africa $\left(\left[0.53 / 100 \mathrm{~K}\right.\right.$ people $\left.\left./ \mathrm{J} / \mathrm{m}^{2}\right] \times 10^{-3}\right)$ or skin type IV-VI African-American blacks in the U.S. ([0.77/100K people $\left./ \mathrm{J} / \mathrm{m}^{2}\right] \times 10^{-3}$ ) have very low incidences similar to the Chinese, Koreans, and Japanese. Note that the AfricanAmerican skin types IV-VI in the U.S. have higher CMM incidences than the lighter skin type IV-V eastern Indians.

\section{Discussion}

Analysis of the incidence of CMM over advancing age of males and females around the world reveals that only European-ancestry females have a linear increase in the incidence with advancing age regardless of Fitzpatrick skin type (I-III or III-IV): skin type I-III (see Figures 1, 4, 5A); skin type III-IV (see Figure 2, top left panel, and Figure 5B); skin type IV (see Figure 3, top two panels), skin type IV-V, and skin type V-VI (see Figure 5C, bottom panels left to right, respectively). All other females and males have a non-linear power function increase in the incidence of CMM with advancing age (see Figure 2 top two panels and bottom right panel, Figure 3 bottom two panels). Because a past investigation only used U.S. data, this linear increase in the incidence of CMM over advancing age was thought to be true for only skin type I-III females. ${ }^{[26]}$ As a result of our worldwide findings showing similar linear increases over age for Fitzpatrick skin type III-IV, we must now address the question, "Why does CMM increase linearly over advancing age exclusively in European-ancestry females regardless of skin type?" We propose the significant gradual lose of bodily androgenic hair during and after menopause in aging European females $(p<.001)^{[27]}$ reduces the risk for getting CMM relative to all males who do not undergo menopause and do not lose as much bodily androgenic hair as they age, and 
other females with lower amounts of androgenic hair lose less hair with age.
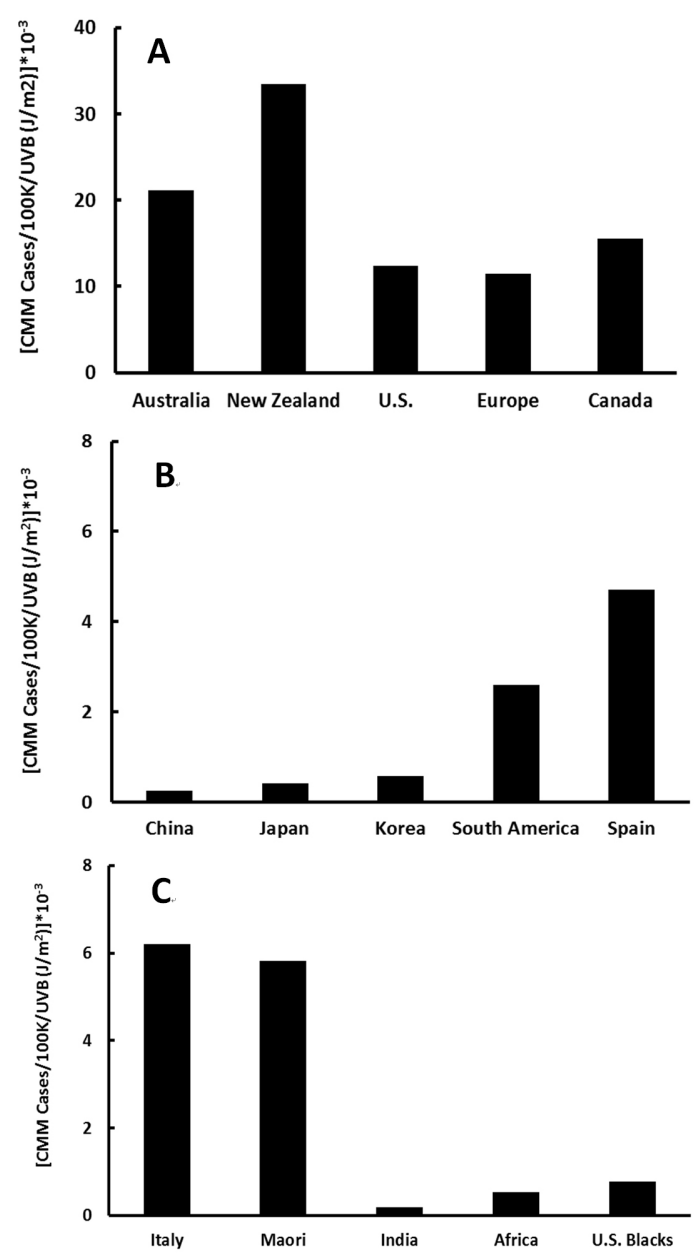

Figure 5. Incidence of CMM per 100,000 people normalized by personal UVB dose $(\mathrm{J} / \mathrm{m} 2) * 10-3$ for A) Fitzpatrick skin type I-III pale skin tone European-ancestry populations, B) Fitzpatrick skin type III-IV with yellow skin tone populations, and C) Fitzpatrick skin type III-IV with olive skin tone Italian and Maori populations, Fitzpatrick skin type IV-V with brown skin tone eastern Indian population, Fitzpatrick skin type III-VI olive, brown, and black skin tone African populations, and Fitzpatrick skin type with brown to black skin tone U.S. African American populations

We can find more evidence that bodily androgenic hair is a major risk factor for getting CMM when we compare the incidences around the world by skin type. We expect darker skin types to be more protective than lighter skin types against UVR-induced damage, so that the order of increase in the incidence of CMM should be by decreasing skin type VI to I. Surprisingly, when we compare the different skin types, we sometimes observe the opposite increase in CMM incidence. For example, skin type IV-VI African-Americans in the U.S. who get lower UVB doses $\left(\sim 9,500-15,000 \mathrm{~J} / \mathrm{m}^{2} / \mathrm{yr}\right.$. $)$ than lighter skin type IV-V in India ( 14,000-20,000 J/m²/yr.) have about three times the incidence of CMM (compare bottom panels in Figure 3 and Figure 5C). Further evidence is obtained from the Northern European skin type I-III populations who, along with the Mediterranean populations, evidently have the most androgenic hair of any population anywhere in the world and also have the highest incidence of CMM in Europe. ${ }^{[8]}$ Paradoxically, they receive some of the lowest annual UVB doses in the world ${ }^{[23]}$ other than Switzerland, Norway, Iceland, and Sweden. When we compare the skin type III-IV populations, we see a very curious phenomena that adds even more evidence that bodily androgenic hair is probably a major risk factor for getting CMM. The Chinese and Japanese populations (see Figure 2 top panels; including the Koreans and Thai, results not shown) have almost ten times lower CMM incidences as the Spanish and South American males and females (see Figure 2 bottom panels); the Chinese have some of the lowest percentages of androgenic body hair with about half the amount that whites have $\mathrm{e}^{[28]}$ and the Japanese have about half the amount that the Germans have ${ }^{[29]}$ who are similar to the Swedes ${ }^{[30]}$ and the European-ancestry populations in North America. ${ }^{[31]}$ For skin type III-IV with olive skin tone, the Italian and Israeli Mediterranean populations (see Figure 3 top panels) with the most androgenic body hair, shows a disproportionate CMM incidence for this skin type compared with the lighter yellow skin tone Spanish and South American skin type III-IV. This may be because they have similar (about 20 to 40 for Italians) or much higher incidences (about 40 to 80 for Israelis) of CMM, which also goes against the belief that skin pigment is protective for CMM, while it adds further support for the belief that the amount of bodily androgenic hair increases the CMM risk. This suggests skin pigment is only somewhat protective against CMM as it also impedes penetration of UVR to the follicular melanocytes.

To obtain more information about the etiology of CMM beyond sex, age, and personal UVR dose, we normalized the average male and female incidence data for all ages (0-85+ yr.) by personal UVB dose which was shown not to correlate with the incidence of CMM in the U.S. ${ }^{[32]} \mathrm{We}$ observe that the skin type I-III European-ancestry populations in Australia and New Zealand have two to three times higher CMM incidences, respectively, than the skin type IIII populations in the U.S., Europe or Canada, which have similar incidences (see Figure 5A). Because UVB is not a factor in this analysis and bodily androgenic hair of European descendants around the world is similar, these differences align with the observed melanocortin-1-receptor gene variants associated with CDKN2A mutation carriers found 
in Australia (and possibly more in New Zealand) that are almost twice as many as those found in Europe. ${ }^{[33]}$ Australia and New Zealand have Europeans who primarily emigrated from England, especially Wales, and Ireland with populations having the highest percentages of red-haired people in the world. More evidence supporting the notion that red hair is important is seen in Figure 5B, where the Chinese, Japanese, and Koreans (along with the Thai, results not shown) having black hair and low percentage of androgenic body hair and they also have the lowest CMM incidences of all the world's populations with skin type IIIIV. The European Spanish population has almost 10 times the incidence that the Asians have and they have considerably more androgenic body hair and some red-haired people with melanocortin-1-receptor variants, ${ }^{[34]}$ whereas the Spanish population in South America that bred with the natives have only about five times the CMM incidence and also have lower percentages of bodily androgenic hair. Figure $5 \mathrm{C}$ of fers more evidence for red hair and melanocortin-1-receptor variants, as the skin type III-IV Italians have more red-haired people and melanocortin-1-receptor variants (and the most androgenic body hair) than the Asian-Indians or Africans (and presumably also the African Americans in the U.S.) who have almost no red hair melanocortin-1-receptor variants (and much lower percentages of androgenic hair) while Britain and Ireland have the most melanocortin-1-receptor variants. ${ }^{[35]}$ The one exception that stands out are the skin type III-IV Polynesian Maori's residing in New Zealand who have a CMM incidence almost as high as the Italians and they also have red haired people. ${ }^{[36]}$ The synthesis of red hair's pheomelanin produces ROS that are not absorbed by that protein as they are by black hair's eumelanin, so that protection against oxidative damage especially to the DNA bases cannot occur. ${ }^{[37]}$ In addition, the aging process produces increasing amounts of ROS primarily due to increasing mitochondrial dysfunction. ${ }^{[38]}$

Apparently the trifecta for getting melanoma involves estrogen and its receptors, HPV, and ROS. Estrogen plays a significant role in the maintenance and development of the hair follicle, ${ }^{[39]}$ an immune privileged site for HPV to hide. ${ }^{[4]}$ Evidence that estrogen synergizes with HPV is provided by cervical cancer, ${ }^{[40]}$ showing that estrogen is responsible for the onset, persistence, and malignant transformation of cervical cells. ${ }^{[41]}$ The mechanism involves estrogen stimulating oncogene expression of HPV E6 and E7 proteins and promoting viral proliferation. ${ }^{[42]}$ ROS synergizes with estrogen to cause cancer, ${ }^{[43]}$ it activates HPV, ${ }^{[44]}$ and HPV's E6 protein can in turn cause production of ROS and DNA damage. ${ }^{[45]}$ The estrogen receptor alpha also plays an important role in this transformation process ${ }^{[40,46]}$ and low levels of vitamin $D_{3}$ help promote cervical cancer. ${ }^{[4]}$ This perfect storm for initiating and promoting cervical cancer probably also applies to other HPV-related cancers like CMM. CMM is also influenced by estrogen and its receptors, ${ }^{[49]}$ over half the biopsies contain HPV, ${ }^{[49]}$ and both dark (pheomelanin synthesis) and light (UVA exposures) ROS production play significant roles in the initiation of melanoma. ${ }^{[50]}$

\section{Conclunsions}

Diseases that involve several causative or potentially causative agents can result in confusing and contradictory studies. Here, we attempt to put together a coherent picture of factors leading to the initiation of CMM that is consistent with the extensive epidemiological information throughout the world. The interaction of melanocytic stem cells, estrogen, $\mathrm{HPV}$, vitamin $\mathrm{D}_{3}$, UV exposure, and age, results in the story of the incidence rates of CMM across the world.

\section{ACKNOWLEDGEMENTS}

The authors wish to thank Dennis L. Lott, Stanely J. Pope, and Drs. Douglas E. Brash and Robert M. Sayre for helpful scientific discussions.

\section{CONFlicts of InTEREST Disclosure}

Authors declare that they have no competing interests.

\section{REFERENCES}

[1] Merrill SJ, Madhan Subramanian M, Godar DE. Worldwide cutaneous malignant melanoma incidences analyzed by sex, age, and skin type over time (1955-2007): Is HPV infection of androgenic hair follicular melanocytes a risk factor for developing melanoma exclusively in people of European-ancestry? Dermato-Endocrinology. 2016; 8: 1, e1215391.

[2] Fitzpatrick TB. The validity and practicality of Sun-reactive skin types I through VI. Arch Dermatol. 1988; 124: 869871. PMid:3377516 https://doi.org/10.1001/archderm.1

\subsection{8}

[3] Curado MP, Edwards B, Shin HR, et al. Cancer Incidence in Five Continents. 2007; Vol. IX IARC Scientific Publications No. 160, Lyon, IARC.

[4] Christoph T, Müller-Röver S, Audring H, et al. The human hair follicle immune system: cellular composition and immune privilege. Br J Dermatol. 2000; 142: 862-873. PMid:10809841 https : //doi.org/10.1046/j.1365-2133.2000.03464.x

[5] Griebeler ML, Kearns AE, Ryu E, et al. Secular trends in the incidence of primary hyperparathyroidism over five decades (1965-2010). 
Bone. 2015; 73: 1-7. PMid:25497786 https://doi .org/10.101 6/j.bone.2014.12.003

[6] Näsman A, Attner P, Hammarstedt L, et al. Incidence of human papillomavirus (HPV) positive tonsillar carcinoma in Stockholm, Sweden: an epidemic of viral-induced carcinoma? Int J Cancer. 2009; 125: 362-366. PMid:19330833 https://doi .org/10.100 2/ijc. 24339

[7] Chaturvedi AK, Engels EA, Pfeiffer RM, et al. Human papillomavirus and rising oropharyngeal cancer incidence in the United States. J Clin Oncol. 2011; 29: 4294-301. PMid:21969503 https: //doi.org/10.1200/JC0.2011.36.4596

[8] Merrill SJ, Ashrafi S, Subramanian M, et al. Exponentially increasing incidences of cutaneous malignant melanoma in Europe correlate with low personal annual UV doses and suggests two major risk factors. Dermato-Endocrinol. 2015; 7(1). PMid:26413188 https://doi.org/10.1080/19381980.2014.1004018

[9] La Placa M, Ambretti S, Bonvicini F, et al. Presence of high-risk mucosal human papillomavirus genotypes in primary melanoma and in acquired dysplastic melanocytic naevi. Br J Dermatol. 2005; 152 : 909-914. PMid:15888145 https://doi.org/10.1111/j.1365 $-2133.2005 .06344 . x$

[10] Boxman ILA, Berkhout RJM, Mulder LHC, et al. Detection of human papillomavirus DNA in plucked hairs from renal transplant recipients and healthy volunteers. J Invest Dermatol. 1997; 108: 712-715. PMid:9129220 https ://doi .org/10.1111/1523-174 7. ep12292090

[11] Le Poole IC, van den Berg FM, van den Wijngaard RM, et al. Generation of a human melanocyte cell line by introduction of HPV16 E6 and E7 genes. In Vitro Cell Dev Biol Anim. 1997; 33: 4249. PMid:9028834 https ://doi .org/10.1007/s11626-997-0 021-6

[12] Gallego MI, Lazo PA. Deletion in human chromosome region 12q13-15 by integration of human papillomavirus DNA in a cervical carcinoma cell line. JBC. 1995; 270: 24321-24326. https: //doi.org/10.1074/jbc.270.41.24321

[13] Danielson C, Fehsel K, Polly P, et al. Differential apoptotic response of human melanoma cells to 1,25-dihydroxyvitamin D3 and its analogues. Cell Death Different. 1998; 5: 946-951. PMid:9846181 https://doi.org/10.1038/sj.cdd.4400437

[14] Cornwell ML, Comstock GW, Holick MF, et al. Prediagnostic serum levels of 1,25-dihydroxyvitamin D and malignant melanoma. Photodermatol Photoimmunol Photomed. 1992; 9: 109-112. PMid:1300138

[15] Berwick M, Armstrong BK, Ben-Porat L, et al. Sun exposure and mortality from melanoma. JNCI. 2005; 97: 195-199. PMid:15687362 https://doi.org/10.1093/jnci/dji019

[16] Devgun MS, Paterson CR, Johnson BE, et al. Vitamin D nutrition in relation to season and occupation. Am J Clin Nutrit. 1981; 34: 1501-1504. PMid:7270473

[17] Gandini S, Sera F, Cattaruza MS, et al. Meta-analysis of risk factors for cutaneous melanoma: II. Sun exposure. Eur J Cancer. 2005; 41: 45-60. PMid:15617990 https://doi.org/10.1016/j.ejca .2004 .10 .016

[18] von Essen MR, Kongsbak M, Schjerling P, et al. Vitamin D controls $\mathrm{T}$ cell antigen receptor signaling and activation of human $\mathrm{T}$ cells. Nat Immunol. 2010; 11: 344-349. PMid:20208539 https : //doi.org/10.1038/ni.1851

[19] Setlow RB, Grist E, Thompson K, et al. Wavelengths effective in induction of malignant melanoma. Proc Natl Acad Sci USA. 1993; 90(14): 6666-6670. PMid:8341684 https ://doi .org/10.1073/ pnas.90.14.6666

Published by Sciedu Press
[20] Godar DE, Landry RJ, Lucas AD. Increased UVA exposures and decreased cutaneous Vitamin D(3) levels may be responsible for the increasing incidence of melanoma. Medical Hypotheses. 2009; 72: 434-443. PMid:19155143 https://doi.org/10.1016/j.me hy. 2008.09.056

[21] Otberg N, Richter H, Schaefer H, et al. Variations of hair follicle size and distribution in different body sites. J Invest Dermatol. 2004; 122: 14-19. PMid:14962084 https://doi.org/10.1046/j.00 22-202X. 2003.22110.x

[22] Crombie IK. Distribution of malignant melanoma on the body surface. Br J Cancer. 1981; 43: 842-849. PMid:7248161 https: //doi.org/10.1038/bjc.1981.123

[23] Godar DE. UV Doses Worldwide. Photochem Photobiol. 2005; 81: 736-749. PMid:15819599 https://doi.org/10.1562/2004-0 9-07-IR-308R. 1

[24] Tributsch H, Goslowsky H, Kuppers U, et al. Light collection and solar sensing through the polar bear pelt. Sol Energy Mater. 1990; 21: 219-236. https://doi.org/10.1016/0165-1633(90) 900 56-7

[25] Pielberg GR, Golovko A, Sundström E, et al. A cis-acting regulatory mutation causes premature hair graying and susceptibility to melanoma in the horse. Nat Genet. 2008; 40: 1004-1009. PMid:18641652 https://doi .org/10.1038/ng. 185

[26] Bloom B, Polsky D. Melanoma in women under age 50: Can genetics work with estrogen to boost the risk? The Melanoma Letter. 2010; 28(1).

[27] Ali I, Wojnarowska F. Physiological changes in scalp, facial and body hair after the menopause: a cross-sectional population-based study of subjective changes. Br J Dermatol. 2011; 164: 508-513. https://doi.org/10.1111/j.1365-2133.2010.10156.x

[28] Lookingbill DP, Demers LM, Wang C, et al. Clinical and biochemical parameters of androgen action in normal healthy Caucasian versus Chinese subjects. J Clin Endocrinol Metab. 1991; 72(6): 1242-8. PMid: 1827450

[29] Matsunaga E. Heredobiologic studies on hair on the middle phalanx of the fingers in Japanese and Germans. Z Mensch Vererb Konstitutionsl. 1956; 33(6): 465-469. PMid:13393213

[30] Beckman L, Book JA. Distribution and Inheritance of Mid-Digital Hair in Sweden. Hereditas. 1959; 45(2-3): 215-220. https ://doi . org $/ 10.1111 / j .1601-5223.1959 . t b 03052 . x$

[31] Danforth CW. Distribution of hair on the digits in man. 1921; 4: 189-204.

[32] Fleischer AB, Fleischer SE. Solar Radiation and the Incidence and Mortality of Leading Invasive Cancers in the United States. Dermato-Endocrinol. https://doi.org/10.1080/19381980.2 016.1162366

[33] Demenais F, Mohamdi H, Chaudru V, et al. Melanoma Genetics Consortium. Association of MC1R variants and host phenotypes with melanoma risk in CDKN2A mutation carriers: a GenoMEL study. JNCI. 2010; 102: 1568-83. PMid:20876876 https ://doi .org/10 $.1093 /$ jnci/djq363

[34] Fernandez L, Milne R, Bravo J, et al. MC1R: three novel variants identified in a malignant melanoma association study in the Spanish population. Carcinogenesis. 2007; 28: 1659-1664. PMid:17434924 https://doi.org/10.1093/carcin/bgm084

[35] Gerstenblith MR, Goldstein AM, Fargnoli MC, et al. Comprehensive evaluation of allele frequency differences of MC1R variants across populations. Hum Mutat. 2007; 28: 495-505. PMid:17279550 https://doi.org/10.1002/humu. 20476

[36] Hiroa TR. Maori Somatology. Racial Averages. J Polynesian Society. 1922; 31: 37-44.

Published by Sciedu Press 
[37] Morgan AM, Lo J, Fisher DE. How does pheomelanin synthesis contribute to melanomagenesis?: Two distinct mechanisms could explain the carcinogenicity of pheomelanin synthesis. Bioessays. 2013; 35(8): 672-6. PMid:23650156 https://doi.org/10.1002/bies .201300020

[38] Cui H, Kong Y, Zhang H. Oxidative stress, mitochondrial dysfunction, and aging. J Signal Transduct. 2012; 2012: 646354. PMid:21977319 https://doi.org/10.1155/2012/646354

[39] Ohnemus U, Uenalan M, Inzunza J, et al. The hair follicle as an estrogen target and source. Endocr Rev. 2006; 27(6): 677-706. PMid:16877675 https ://doi .org/10.1210/er. 2006-0020

[40] Chung SH, Franceschi S, Lambert PF. Estrogen and ERalpha: culprits in cervical cancer? Trends Endocrinol Metab. 2010; 21(8): 504-11. PMid:20456973 https ://doi .org/10.1016/j.tem. 20 10.03.005

[41] Brake T, Lambert PF. Estrogen contributes to the onset, persistence, and malignant progression of cervical cancer in a human papillomavirus-transgenic mouse model. Proc Natl Acad Sci USA. 2005; 102(7): 2490-2495. PMid:15699322 https : //doi .org/10 $.1073 /$ pnas. 0409883102

[42] Au WW, Abdou-Salama S, Al-Hendy A. Inhibition of growth of cervical cancer cells using a dominant negative estrogen receptor gene. Gynecol Oncol. 2007; 104(2): 276-280. PMid:17137618 https://doi.org/10.1016/j.ygyno.2006.10.015

[43] Bhat HK, Calaf G, Hei TK, et al. Critical role of oxidative stress in estrogen-induced carcinogenesis. Proc Natl Acad Sci USA. 2003; 100: 3913-3918.
[44] De Marco F. Oxidative stress and HPV carcinogenesis. Viruses. 2013; 5(2): 708-31. PMid:12655060 https://doi.org/10.1073/pnas .0437929100

[45] Williams VM, Filippova M, Filippov V, et al. Human papillomavirus type 16 E6* induces oxidative stress and DNA damage. J Virol. 2014; 88(12): 6751-61. PMid:23403708 https://doi.org/10.3390/ v5020708

[46] Shew ML, McGlennen R, Zaidi N, et al. Oestrogen receptor transcripts associated with cervical human papillomavirus infection. Sex Transm Infect. 2002; 78(3): 210-214. PMid:12238657 https : //doi.org/10.1136/sti.78.3.210

[47] Shim J, Pérez A, Symanski E, et al. The Association between Serum 25-hydroxyvitamin D and Human Papillomavirus Cervicovaginal Infection in Women in the United States. J Infect Dis. 2016; 213(12): 1886-1892. PMid:26908722 https ://doi.org/10.109 3/infdis/jiw065

[48] de Giorgi V, Gori A, Alfaioli B, et al. Influence of sex hormones on melanoma. J Clin Oncol. 2011; 29(4): e94-5. PMid:21172886 https://doi.org/10.1200/JC0.2010.33.1876

[49] Dréau D, Culberson C, Wyatt S, et al. Human papilloma virus in melanoma biopsy specimens and its relation to melanoma progression. Ann Surg. 2000; 231: 664-671. PMid:10767787 https : //doi .org/10.1097/00000658-200005000-00006

[50] Napolitano A, Panzella L, Monfrecola G, et al. Pheomelanin-induced oxidative stress: bright and dark chemistry bridging red hair phenotype and melanoma. Pigment Cell Melanoma Res. 2014; 27(5): 72133. PMid:24814217 https ://doi.org/10.1111/pcmr. 12262 